\title{
molecules
}

ISSN 1420-3049

www.mdpi.com/journal/molecules

Article

\section{Photochemical Synthesis of Nucleoside Analogues from Cyclobutanones: Bicyclic and Isonucleosides}

\section{Mileina Jaffer, Abdelaziz Ebead and Edward Lee-Ruff *}

Department of Chemistry, York University, 4700 Keele Street, Toronto, Ontario, M2M 4J4, Canada

* Author to whom correspondence should be addressed; E-Mail: leeruff@yorku.ca;

Tel.: +1-416-736-5443; Fax: +1-416-736-5936.

Received: 8 April 2010; in revised form: 19 May 2010 / Accepted: 24 May 2010 /

Published: 26 May 2010

\begin{abstract}
The preparation of two nucleoside analogues are reported. Both syntheses involve a key photochemical ring-expansion of cyclobutanones to an oxacarbene and its subsequent scavenging by 6-chloropurine. The synthesis of a bicyclic (locked) purine starts from a oxabicycloheptanone with a hydroxymethyl pendant. The preparation of an isonucleoside uses a cyclobutanone with an $\alpha$-substituted 6-chloropurine. Irradiation of the latter produces an isonucleoside and acyclic nucleoside analogues.
\end{abstract}

Keywords: cyclobutanone; oxacarbene; bicyclic nucleosides; isonucleosides; acyclic nucleoside

\section{Introduction}

Structurally modified nucleosides represent an important class of medicinal compounds which have been found to behave as therapeutic agents and are currently used in pharmaceuticals as antitumour, antiviral, and antibiotic agents [1-4]. Structural modifications include the ribose, as well as the base moieties. The general synthetic protocols involve the use of monosaccharide chirons which are coupled to heterocycles employing a key glycosylation step which is often not stereoselective. During the last decade our group has developed a photochemical glycosylation method based on the photoisomerization of cyclobutanones to transient 2-tetrahydrofuranylidenes and their insertion into alcohols [5] or weakly acidic N-H functions (Scheme 1) [6-11,13]. 
Scheme 1. N-Glycosylation by Photochemical Ring-expansion of Cyclobutanones.

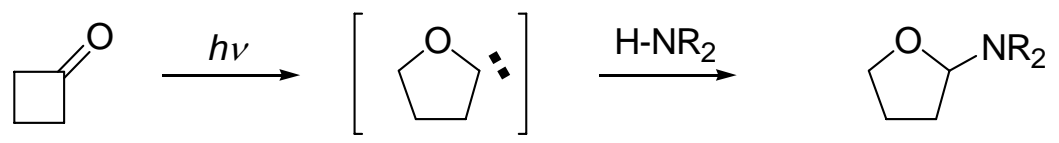

The $\mathrm{N}$-glycosylation procedure was exploited for the preparation of modified ribonucleosides [6-11,13]. Although anomeric mixtures were obtained, some stereoselectivity was observed, depending on the nature of the ring substituents. The advantages of this method are the mild conditions for coupling (neutral solutions), the retention of stereochemistry of the cyclobutanone ring substituents in the photoproducts, and the availability of substituted cyclobutanone precursors with defined stereochemistry using relatively simple methods $[14,15]$. These precursors can also be prepared in chiral modifications for their use in the preparation of chiral nucleosides.

In the current investigation we report the synthesis of two new nucleoside analogues, a bicyclic ("locked") derivative and an isonucleoside, from two different cyclobutanone precursors. Furthermore, photocycloelimination of cyclobutanones results in the stereospecific formation of alkenes as a side reaction. The extent to which cycloelimination occurs is dependent on the electronic nature of the $\alpha$ substituent in the ketone as well as solvent effects. Electron-withdrawing groups promote cyloelimination over photoisomerization [16]. We also report the stereoselective formation of an acyclic nucleoside analogue from the photocycloelimination of an $\alpha$-nucleobase-substituted cyclobutanone.

\section{Results and Discussion}

\subsection{Photochemical Synthesis of a Bicyclic Nucleoside Analogue}

A class of structurally modified nucleosides consists of bicyclic or "locked" derivatives. In this class of nucleosides, there is an additional ring fused to the sugar moiety [17]. The five membered sugar rings found in nucleosides exist in a puckered geometry. Figure 1 depicts this geometry in either the "south" or the "north" conformation. The two conformers are in equilibrium.

Figure 1. Nucleoside Conformations.

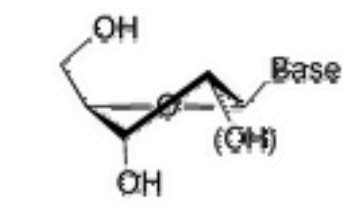

C2 Endo (South)

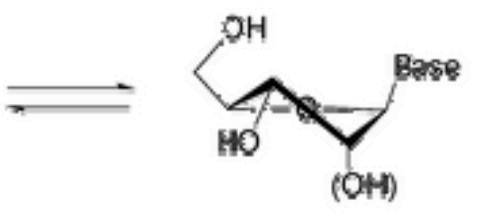

C3 Endo (North)

The specific conformation is crucial for complementary binding with target molecules. An attractive feature of bicyclic derivatives is their restricted conformational flexibility [17]. Thus, the nucleoside may be locked in the active conformation (either north or south) required to show activity. Due to their decreased conformational flexibility, oligonucleotides incorporating these rigid nucleoside analogues have been observed to display increasing recognition of DNA sequences [17]. The ability of nucleotides containing locked nucleoside to be able to recognize DNA sequences have rendered these 
promising as drug candidates for antisense therapy. We have previously reported the photochemical ring-expansion of a series of bicyclic cyclobutanones and their carbene insertion reactions to 6-chloropurine in order to explore this approach for the preparation bicyclic nucleoside analogues [13]. The earlier report was to demonstrate the proof of concept, but did not incorporate important structural features associated with substituents necessary for biological functions (i.e. hydroxymethyl, hydroxyl groups). In the current study we report the preparation of nucleoside analogues 1a and 1b (Figure 2) with the appropriate hydroxymethyl substituent for binding to the phosphorylating kinase receptor [18] using the photochemical protocol developed by our group.

Figure 2. Target Bicyclic Derivatives.<smiles>[R]C[C@]12C[C@@H](n3cnc4c([R])ncnc43)O[C@@H]1CCO2</smiles>

$1 \mathrm{a}$<smiles>[R]C[C@]12C[C@@H](n3cnc4c([R])ncnc43)O[C@@H]1CCO2</smiles>

$\mathbf{1 b}$

$$
\begin{aligned}
& \mathrm{R}=\mathrm{OBn}, \mathrm{H} \\
& \mathrm{R}^{\prime}=\mathrm{Cl}, \mathrm{NH}_{2}
\end{aligned}
$$

The bicycloheptanone 3 was prepared in two steps from the previously reported 2benzyloxymethyl-4,5-dihydrofuran (2) [19] using the standard [2+2] dichloroketene cycloaddition and dechlorination sequence. Although the overall yield for the two steps is low $(\sim 10 \%)$ no optimization was carried out and significant amounts of starting $\mathbf{2}$ accompanied product formation. The regioselectivity for the cycloaddition follows previously observed ketene cycloadditions to vinyl ethers [20]. Irradiation of ketone 3 with 6-chloropurine in acetonitrile solution produced a diastereomeric mixture of two anomers $\mathbf{1 a}$ and $\mathbf{1 b}$ in a 2:1 ratio (30\%) (Scheme 2).

Scheme 2. Preparation of a Bicyclic Nucleoside Analogue.

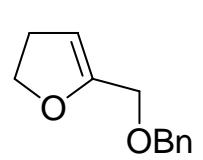

2

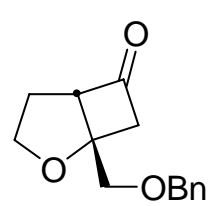

3<smiles>C[C@H]1CC2O[C@@H](n3cnc4c(Cl)ncnc43)C[C@]2(COCc2ccccc2)O1</smiles>

$1 a$

$1 \mathbf{b}$

(a) DCAC, TEA in hexane or TCAC/Zn-Cu couple, ether, DME ; (b) Zn-Cu couple, $\mathrm{NH}_{4} \mathrm{Cl}$ $\mathrm{MeOH},\left(10 \%\right.$ overall yield); (c) $h v$, 6-chloropurine, $\mathrm{CH}_{3} \mathrm{CN}(31 \%)$

The remaining products consisted of polar materials which were not identified. Photocycloelimination is known to accompany ring-expansion, the latter pathway leading to a substituted ketene which could oligomerize or produce carboxylic acids on work up [16]. The regioselectivity for insertion of the oxacarbene to the N-9 position has been established from previous studies [6,8-11] with the predominant presence of the $\mathrm{N}-9(\mathrm{H})$ tautomer in solution. The major epimer was shown to 
possess the exo stereochemistry on the basis of 1D and 2D (HSQC, COSY and NOESY). For 1a the NOE correlation was established between the anomeric and the bridgehead protons. For $\mathbf{1 b}$ there was no observable correlation between these respective protons. The cis-fused assignment of both epimers was established by NOE correlation between the bridgehead and methylene protons. This observation is consistent with the retention of the ring substituent stereochemistry in these photochemical ringexpansions of cyclobutanones.

The preference for formation of the exo-adduct is likely due to the less sterically encumbered exoapproach of the carbene scavenger. The conversion of the chloro-nucleosides to the adenine derivatives, 1a and 1b $\left(\mathrm{R}^{\prime}=\mathrm{NH}_{2}\right)$ as well as deprotection of the alcohol group are straightforward steps. Our investigations are continuing on extensions to the homologous dihydropyran series, although these would be more conformationally flexible than the corresponding furan series.

\subsection{Synthesis of Acyclic and Isonucleoside Analogues from the same Cyclobutanone Precursor}

Isonucleosides are analogues in which the substituents of the ribose moiety are transposed to different positions in the sugar ring from their natural counterpart [21]. Acyclic nucleosides incorporate a non cyclic ribose equivalent [22]. Many of these exhibit antiviral activity such as acyclovir which is used in the treatment of most forms of herpes.

In a separate study involving the preparation of cyclobutane carbocyclic analogues of nucleosides we synthesized ketone 4 by way of $N$-alkylation of 2-bromo-3-benzoylxycyclobutanone [10] with 6chloropurine [23]. The stereochemistry of $\mathbf{4}$ was confirmed from the X-ray crystal structure analysis of one of its derivatives. Photochemical ring-expansion in the presence of water should result in hemiacetal 5 which on deprotection and aminolysis, carried out in a one pot reaction, would give isoadenosine 6 (Scheme 3). Regioselectivity would be expected from scission of the more substituted carbonyl carbon bond.

Scheme 3. Preparation of an Isonucleoside.

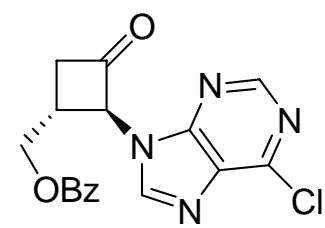

4

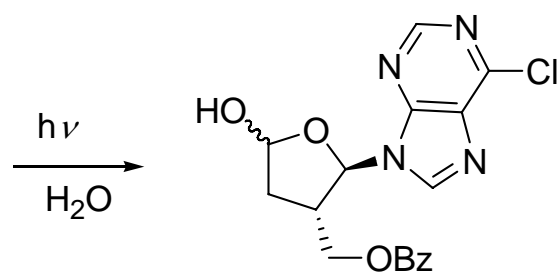

5

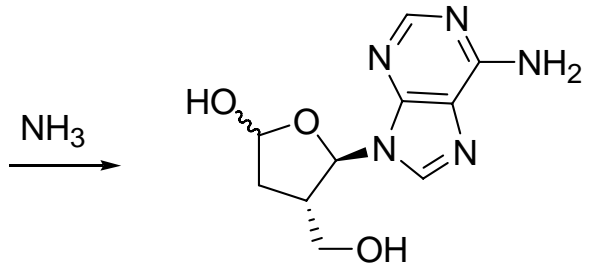

6

Irradiation of 4 in acetonitrile containing 10 stoichiometric equivalents of water produced, in addition to 5 (20\%), geometric isomers 7 (11\%) and 8 (64\%) derived from cycloelimination of ketene Scheme 4). The hemiacetal 5 was formed as a single stereoisomer as was evident by the simple doublet signal observed for the anomeric proton of the aminoacetal group, although the relative stereochemistry of the hemiacetal group could not be unambiguously assigned. The formation of the cis-isomer $\mathbf{8}$ as the major product was unexpected as the fragmentation of ketene from electronically 
excited cyclobutanones is known to be a concerted process originating from the singlet state and leads to alkenes with retention of stereochemistry.

Scheme 4. Photochemical Production of an Isonucleoside and Acyclic Derivatives.<smiles>O=C(O)C[C@H]1CC(=O)[C@@H]1n1cnc2c(Cl)ncnc21</smiles>

4

$$
\frac{\mathrm{h} v / 3 \mathrm{~h} .}{\mathrm{CH}_{3} \mathrm{CN} / \mathrm{H}_{2} \mathrm{O}}
$$

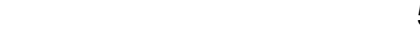<smiles>O=C(OC/C=C/n1cnc2c(Cl)ncnc21)OCc1ccccc1</smiles>

7<smiles></smiles>

8

Photocycloelimination of ketene is regioselective, involving cleavage of the more substituted $\alpha$ carbon-carbonyl carbon bond similar to the regioselectivity of the ring-expansion reaction. The extent to which each of these competitive processes occur is influenced by the nature of the $\alpha$-substituent with electron-withdrawing groups favouring cycloeliminations and electron-donating groups giving ring-expansion oxacarbene photoadducts [16]. The distribution of these two competitive pathways is also affected by solvent polarity, with polar solvents favouring ring-expansion and non-polar solvents giving rise to cycloeliminations [16]. The solvent effects on the distribution of products is attributed to reversible formation of the more polar oxacarbene intermediate [16].

In order to maximize the yields of the ring-expansion photoadducts, the photolysis of $\mathbf{4}$ was carried out in more polar methanol solutions (Scheme 5). The yield for the ring-expansion photoadduct 9 increased to $40 \%$. Under these conditions a small amount of $8(13 \%)$ was observed with no detectable presence of $\mathbf{7}$. However, a new photoadduct $\mathbf{1 0}$ was observed in $21 \%$ yield.

Scheme 5. Photochemical Production of an Isonucleoside and Acyclic Derivative.<smiles>CCCCOC[C@H]1CC(=O)C1n1cnc2c(Cl)ncnc21</smiles>

4

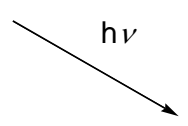

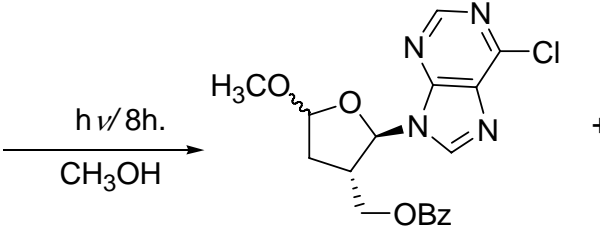

9

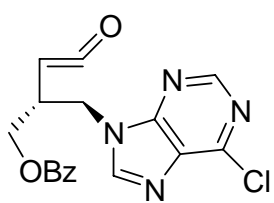

11<smiles>COC(=O)CC(CO)Cn1c([18O])nc2c(Cl)ncnc21</smiles>

10

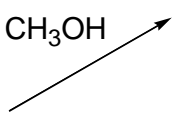

The latter is likely formed from a Norrish Type I reaction involving a transient ketene 11. This mode for deactivation is unusual for cyclobutanones which yield photoproducts originating from the singlet state on direct irradiation. Ketene formation from Norrish I reactions normally originate from 
the triplet state in acyclic and medium size cycloalkanones [24]. Diester $\mathbf{1 0}$ would serve as an important precursor to potential biologically active acyclic nucleosides on reduction-deprotection and aminolysis.

The purine substituted alkenes $\mathbf{7}$ and $\mathbf{8}$ are also important precursors to other acyclic nucleoside as well as cyclopropane analogues. The effect of less polar solvents such as benzene and acetone on the photochemistry of ketone 4 was investigated with the objective of maximizing the cycloelimination pathway. Both solvents yielded alkenes $\mathbf{7}$ and $\mathbf{8}$ as the only identifiable products, however the total yield for $\mathbf{7}$ and $\mathbf{8}$ was lower than that obtained in acetonitrile. In benzene trans- $\mathbf{7}$ exceeded cis-8 by a factor of 2:1. For acetone, a known triplet sensitizer, the distribution of $\mathbf{7}$ and $\mathbf{8}$ was about the same. The unusual non-steroselective photocycloelimination observed in the case of ketone 4 is likely the result of concurrent photoisomerization between $\mathbf{7}$ and $\mathbf{8}$ as was shown by independent experiments under the conditions of direct or sensitized irradiation.

\section{Experimental}

\subsection{General}

Photolyses were carried out using a Hanovia 450-W medium pressure mercury arc lamp in a watercooled quartz immersion well. Pyrex tubes containing the samples were strapped around this well, and the assembly was immersed in an ice-water bath. The samples were purged with argon for 30 min prior to irradiation. All solvents used were dried and distilled. Proton NMR spectra were obtained on a Bruker ARX-400 spectrometer and ${ }^{13} \mathrm{C}$ NMR was carried out on a Bruker 300 spectrometer. Mass Spectra were collected (EI mode) using a Varian Series 4000 GC/MS/MS spectrometer.

\subsection{1-(Benzyloxymethyl)-7,7-dichloro-2-oxabicyclo[3.2.0] heptan-6-one}

\subsubsection{Method A}

Enol ether 2 [20] (2.36 g, $0.0124 \mathrm{~mol})$ was dissolved in hexanes $(60 \mathrm{~mL})$ and stirred at room temperature. Dichloroacetyl chloride $(1.92 \mathrm{~g}, 0.015 \mathrm{~mol})$ was added and the mixture was allowed to reflux for $20 \mathrm{~min}$. Triethylamine $(1.50 \mathrm{~g}, 0.015 \mathrm{~mol})$ in hexanes $(30 \mathrm{~mL})$ was then added dropwise to the mixture. The reaction was allowed to stir for $1 \mathrm{~h}$ and quenched with cold $\mathrm{H}_{2} \mathrm{O}(30 \mathrm{~mL})$. The organic layer was washed with saturated $\mathrm{NaHCO}_{3}$, dried over $\mathrm{Na}_{2} \mathrm{SO}_{4}$, and the solvent was removed under vacuum to give the title compound in $21 \%$ yield. IR $\left(1,805 \mathrm{~cm}^{-1}\right)$ confirmed the presence of the cyclobutanone carbonyl group. The crude material was used immediately for the dechlorination step without purification.

\subsubsection{Method B}

To a solution of alkene $2(4.022 \mathrm{~g}, 0.0212 \mathrm{~mol})$ in ether $(80 \mathrm{~mL})$ and DME $(11 \mathrm{~mL})$ was added $\mathrm{Zn} / \mathrm{Cu}$ couple [25] (4.29 g). The mixture was heated to reflux and trichloroacetyl chloride (TCAC) (10.409 g, $0.05724 \mathrm{~mol})$ was added dropwise to the mixture. The mixture was allowed to reflux overnight. Zinc precipitate was filtered and the ether was evaporated under reduced pressure. The residue was dissolved in hexanes and the organic layer was washed twice with saturated $\mathrm{NaHCO}_{3}$ 
solution. The organic layer was then washed with brine, dried over $\mathrm{Na}_{2} \mathrm{SO}_{4}$, and the solvent was removed under reduced pressure to give the title compound which showed identical spectral properties as the sample obtained from method A.

\subsection{1-(Benzyloxymethyl)-2-oxabicyclo[3.2.0]heptan-6-one (3)}

\subsubsection{Method A}

Dichloroketone $(0.372 \mathrm{~g}, 0.00123 \mathrm{~mol})$ obtained above was stirred in $\mathrm{MeOH}(30 \mathrm{~mL})$ at $0{ }^{\circ} \mathrm{C}$. To this solution, zinc powder $(0.88 \mathrm{~g}, 0.013 \mathrm{~mol})$ and ammonium chloride $(0.48 \mathrm{~g}, 0.009 \mathrm{~mol})$ was added. The mixture was allowed to stir and warm to room temperature overnight. The zinc was filtered and the solvent was removed under reduced pressure. The residue was dissolved in ether $(3 \times 20 \mathrm{~mL})$ and the organic layer was washed with $2 \times 15 \mathrm{~mL}$ saturated $\mathrm{NaHCO}_{3}$, dried over $\mathrm{Na}_{2} \mathrm{SO}_{4}$, and the solvent removed under reduced pressure to give an oil which was purified by preparative TLC (30\% ethyl acetate in hexanes). Yield 10\%. IR $\left(\mathrm{cm}^{-1}\right): 1807 ;{ }^{1} \mathrm{H}-\mathrm{NMR}\left(\mathrm{CDCl}_{3}\right): \delta 7.30-7.38(\mathrm{~m}, 5 \mathrm{H}), 4.66-4.70$ (m, 2H), 4.21-4.28 (m, 1H), 3.97-4.03 (m, 1H), 3.82-3.84 (m, 2H), 3.64-3.68 (m, 1H), 3.21-3.29 (dd, $J=5.4 \mathrm{~Hz}, 18 \mathrm{~Hz}, 1 \mathrm{H}), 2.93-3.00(\mathrm{dd}, J=2.1 \mathrm{~Hz}, 18 \mathrm{~Hz}, 1 \mathrm{H}), 1.90-2.22(\mathrm{~m}, 2 \mathrm{H}) ;{ }^{13} \mathrm{C}-\mathrm{NMR}$ $\left(300 \mathrm{MHz}, \mathrm{CDCl}_{3}\right): \delta 214(\mathrm{C}=\mathrm{O}, \mathrm{C}-1), 65.38(\mathrm{CH}, \mathrm{C}-2), 29.4\left(\mathrm{CH}_{2}, \mathrm{C}-3\right), 69.2\left(\mathrm{CH}_{2}, \mathrm{C}-4\right), 29.9(\mathrm{C}, \mathrm{C}-$ 5), $53.2\left(\mathrm{CH}_{2}, \mathrm{C}-6\right), 71.7\left(\mathrm{CH}_{2}, \mathrm{C}-7\right), 73.6\left(\mathrm{CH}_{2}, \mathrm{C}-8\right) 138(\mathrm{C}, \mathrm{C}-9), 127.8-130.6(\mathrm{CH}, \mathrm{C}-10) ;{ }^{1} \mathrm{H}-$ and ${ }^{13} \mathrm{C}-\mathrm{NMR}$ assignments from COSY, HSQC and NOESY data are given in Table 1; MS (EI) m/z $232\left(\mathrm{M}^{+}\right)$.

Table 1. Assignment of ${ }^{13} \mathrm{C}$ and ${ }^{1} \mathrm{H}$ Chemical Shift Values from COSY, HSQC and NOESY Data.

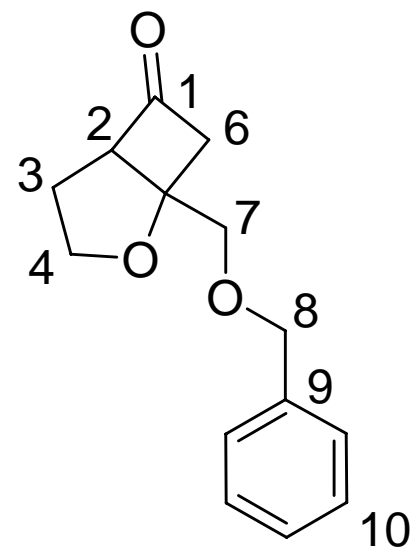

\begin{tabular}{|l|l|l|}
\hline Carbon No. & ${ }^{13} \mathbf{C} \boldsymbol{\delta}(\mathbf{p p m})$ & ${ }^{1} \mathbf{H} \boldsymbol{\delta}(\mathbf{p p m})$ \\
\hline 1 & 214 & \\
2 & 65.4 & $3.64-3.68(\mathrm{~m}, 1 \mathrm{H})$ \\
3 & 29.37 & $1.90-2.22(\mathrm{~m}, 2 \mathrm{H})$ \\
4 & 69.20 & $3.97-4.03(\mathrm{~m}, 1 \mathrm{H})$ \\
& & $4.21-4.28(\mathrm{~m}, 1 \mathrm{H})$ \\
5 & 29.9 & \\
6 & 53.1 & $3.21-3.29(\mathrm{dd}, J=5.4 \mathrm{~Hz}, 18 \mathrm{~Hz}, 1 \mathrm{H})$ \\
& & $2.93-3.00(\mathrm{dd}, J=2.1 \mathrm{~Hz}, 18 \mathrm{~Hz}, 1 \mathrm{H})$ \\
7 & 71.6 & $3.82-3.89(\mathrm{~m}, 2 \mathrm{H})$ \\
8 & 73.5 & $4.66-4.70(\mathrm{~m}, 2 \mathrm{H})$ \\
9 & 138 & \\
10 & $127.7-130.6$ & $7.30-7.38(\mathrm{~m}, 5 \mathrm{H})$ \\
\hline
\end{tabular}




\subsubsection{Method B}

To a stirring mixture of 1-(benzyloxymethyl)-7,7-dichloro-2-oxabicyclo[3.2.0]heptan-6-one obtained above $(1.75 \mathrm{~g}, 0.0096 \mathrm{~mol})$ and ammonium chloride $(2.59 \mathrm{~g}, 0.048 \mathrm{~mol})$ in methanol $(41 \mathrm{~mL})$ was added zinc-copper couple $(1.90 \mathrm{~g})$ at room temperature. The reaction mixture was stirred for $1 \mathrm{~h}$. The zinc precipitate was filtered and the filtrate was concentrated. The residue was dissolved in DCM, and the solution was washed with brine, dried over anhydrous sodium sulphate, filtered, and concentrated. The residue was purified by preparative TLC (30\% ethyl acetate-hexanes). Yield 10\%. The sample obtained showed identical spectral properties with those of the sample obtained from method A.

\subsection{9-(3a-(Benzyloxymethyl)dihydrofuro[3,2-b]furan-2-yl)-6-chloro-9H-purine (1a and 1b)}

A solution of ketone $3(0.085 \mathrm{~g}, 0.00037 \mathrm{~mol})$ and 6-chloropurine $(0.085 \mathrm{~g}, 0.0006 \mathrm{~mol})$ in acetonitrile $(80 \mathrm{~mL})$ was irradiated for $6 \mathrm{~h}$ in a pyrex tube. The solvent was removed under reduced pressure and the residue dissolved in chloroform. The photolysate were purified by preparative TLC (70\% ethyl acetate-hexanes) giving $\mathbf{1 a}(20 \%)$ and $\mathbf{1 b}(10 \%)$ as oils.

Nucleoside 1a: ${ }^{1} \mathrm{H}-\mathrm{NMR}\left(\mathrm{CDCl}_{3}, 400 \mathrm{MHz}\right): \delta 8.70(\mathrm{~s}, 1 \mathrm{H}), 8.45(\mathrm{~s}, 1 \mathrm{H}), 7.25-7.37(\mathrm{~m}, 5 \mathrm{H})$, 6.53-6.55 (dd, $J=5.2 \mathrm{~Hz}, 7.2 \mathrm{~Hz}, 1 \mathrm{H}), 4.90$ (d, $J=4.4 \mathrm{~Hz}, 1 \mathrm{H}), 4.5$ (AB q, $J=12 \mathrm{~Hz}, 2 \mathrm{H}), 4.04-4.14$ $(\mathrm{m}, 2 \mathrm{H}), 3.66(\mathrm{~d}, J=9.6 \mathrm{~Hz}, 1 \mathrm{H}), 3.53(\mathrm{~d}, J=9.6 \mathrm{~Hz}, 1 \mathrm{H}), 3.02(\mathrm{dd}, J=5.2 \mathrm{~Hz}, 14.4 \mathrm{~Hz}, 1 \mathrm{H}), 2.81$ $(\mathrm{dd}, J=7.2 \mathrm{~Hz}, 14.4 \mathrm{~Hz}, 1 \mathrm{H}), 2.12-2.23(\mathrm{~m}, 2 \mathrm{H}) ;{ }^{13} \mathrm{C}-\mathrm{NMR}\left(\mathrm{CDCl}_{3}, 300 \mathrm{MHz}\right): \delta 92.2(\mathrm{CH}, \mathrm{C}-1)$, $33.2\left(\mathrm{CH}_{2}, \mathrm{C}-2\right), 73.6\left(\mathrm{CH}_{2}, \mathrm{C}-3\right), 70.7\left(\mathrm{CH}_{2}, \mathrm{C}-5\right), 67.9\left(\mathrm{CH}_{2}, \mathrm{C}-4\right), 76.6(\mathrm{C}, \mathrm{C}-7), 41.914\left(\mathrm{CH}_{2}, \mathrm{C}-8\right)$, 86.1 (CH, C-9), 126.0-127.8 (CH, C-6), 143.5 (CH, C-10), 151.9 (CH, C-11); MS (EI) m/z 388 (M , $\left.{ }^{37} \mathrm{Cl}\right), 386\left(\mathrm{M}^{+},{ }^{35} \mathrm{Cl}\right) ;{ }^{1} \mathrm{H}-$ and ${ }^{13} \mathrm{C}-\mathrm{NMR}$ assignments from COSY, HSQC and NOESY data are given in Table 2.

Nucleoside 1b: ${ }^{1} \mathrm{H}-\mathrm{NMR}\left(\mathrm{CDCl}_{3}, 300 \mathrm{MHz}\right): \delta 8.59$ (s, 1H), $8.79(\mathrm{~s}, 1 \mathrm{H}), 7.28-7.40(\mathrm{~m}, 5 \mathrm{H}), 6.47-6.49$ $(\mathrm{dxd}, J=3.9 \mathrm{~Hz}, 7.8 \mathrm{~Hz}, 1 \mathrm{H}), 4.73(\mathrm{~d}, J=2.4 \mathrm{~Hz}, 1 \mathrm{H}), 4.63(\mathrm{~s}, 2 \mathrm{H}), 4.09$ (m, 2H), 3.63 (d, $J=9.6 \mathrm{~Hz}$, $1 \mathrm{H}), 3.54(\mathrm{~d}, J=9.6 \mathrm{~Hz}, 1 \mathrm{H}), 2.99(\mathrm{dd}, J=7.8 \mathrm{~Hz}, 14.7 \mathrm{~Hz}, 1 \mathrm{H}), 2.76(\mathrm{dd}, J=3.6 \mathrm{~Hz}, 14.7 \mathrm{~Hz}, 1 \mathrm{H})$, 2.13-2.19 (m, 2H); ${ }^{13} \mathrm{C} \mathrm{NMR}\left(\mathrm{CDCl}_{3}, 300 \mathrm{MHz}\right): \delta 87.266(\mathrm{CH}, \mathrm{C}-1), 32.777\left(\mathrm{CH}_{2}, \mathrm{C}-2\right), 73.738$ $\left(\mathrm{CH}_{2}, \mathrm{C}-3\right), 68.196\left(\mathrm{CH}_{2}, \mathrm{C}-4\right), 70.931\left(\mathrm{CH}_{2}, \mathrm{C}-5\right), 76.00(\mathrm{C}, \mathrm{C}-7), 40.108\left(\mathrm{CH}_{2}, \mathrm{C}-8\right), 84.240(\mathrm{CH}, \mathrm{C}-$ 9), 143.981 (CH, C-10), 127.304-128.577 (CH, C-6), $152.214(\mathrm{CH}, \mathrm{C}-11)$; MS (EI) m/z $388\left(\mathrm{M}^{+}\right.$, $\left.{ }^{37} \mathrm{Cl}\right), 386\left(\mathrm{M}^{+},{ }^{35} \mathrm{Cl}\right)$; ${ }^{1} \mathrm{H}$ - and ${ }^{13} \mathrm{C}-\mathrm{NMR}$ assignments from COSY, HSQC and NOESY data are given in Table 2.

Table 2. Assignment of ${ }^{13} \mathrm{C}$ and ${ }^{1} \mathrm{H}$ Chemical Shift Values from COSY, HSQC and NOESY Data. 


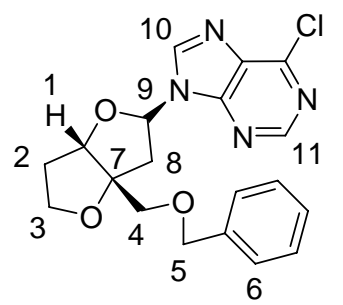

Table 2. Cont.

\begin{tabular}{|l|l|l|}
\hline Carbon No. & ${ }^{13} \mathbf{C} \boldsymbol{\delta}(\mathbf{p p m})$ & ${ }^{1} \mathbf{H} \boldsymbol{\delta}(\mathbf{p p m})$ \\
\hline 1 & 92.2 & $4.90(\mathrm{~d}, J=4.4 \mathrm{~Hz}, 1 \mathrm{H})$ \\
2 & 33.2 & $2.12-2.23(\mathrm{~m}, 2 \mathrm{H})$ \\
3 & 73.6 & $4.04-4.14(\mathrm{~m}, 2 \mathrm{H})$ \\
4 & 67.9 & $3.66(\mathrm{~d}, J=9.6 \mathrm{~Hz}, 1 \mathrm{H}), 3.53(\mathrm{~d}, J=9.6 \mathrm{~Hz}, 1 \mathrm{H})$ \\
\hline 5 & 70.7 & $4.5(\mathrm{AB} \mathrm{q}, J=12 \mathrm{~Hz}, 2 \mathrm{H})$ \\
6 & $126.0-127.8$ & $7.25-7.37(\mathrm{~m}, 5 \mathrm{H})$ \\
7 & 76.6 & \\
8 & 41.9 & $2.81(\mathrm{dd}, J=7.2 \mathrm{~Hz}, 14.4 \mathrm{~Hz}, 1 \mathrm{H})$ \\
& & $3.02(\mathrm{dd}, J=5.2 \mathrm{~Hz}, 14.8 \mathrm{~Hz}, 1 \mathrm{H})$ \\
9 & 86.1 & $6.53-6.55(\mathrm{dd}, J=5.2 \mathrm{~Hz}, 7.2 \mathrm{~Hz}, 1 \mathrm{H})$ \\
10 & 143.5 & $8.45(\mathrm{~s}, 1 \mathrm{H})$ \\
11 & 151.9 & $8.70(\mathrm{~s}, 1 \mathrm{H})$ \\
\hline
\end{tabular}

Minor nucleoside 1b:

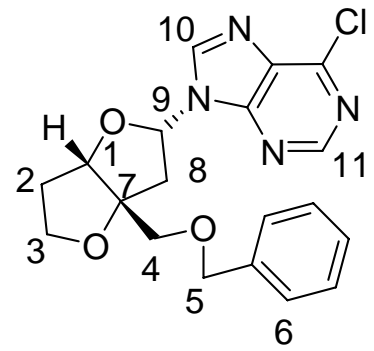

\begin{tabular}{|l|l|l|}
\hline Carbon No. & ${ }^{13} \mathbf{C} \boldsymbol{\delta}(\mathbf{p p m})$ & ${ }^{1} \mathbf{H} \boldsymbol{\delta}(\mathbf{p p m})$ \\
\hline 1 & 87.3 & $4.73(\mathrm{~d}, J=2.4 \mathrm{~Hz}, 1 \mathrm{H})$ \\
2 & 32.8 & $2.13-2.19(\mathrm{~m}, 2 \mathrm{H})$ \\
3 & 73.7 & $4.09(\mathrm{~m}, 2 \mathrm{H})$ \\
4 & 68.2 & $3.63(\mathrm{~d}, J=9.6 \mathrm{~Hz}, 1 \mathrm{H}), 3.54(\mathrm{~d}, J=9.6 \mathrm{~Hz}, 1 \mathrm{H})$ \\
5 & 70.9 & $4.63(\mathrm{~s}, 2 \mathrm{H})$ \\
6 & $127.3-128.6$ & $7.28-7.40(\mathrm{~m}, 5 \mathrm{H})$ \\
7 & 76.0 & \\
8 & 40.1 & $2.99(\mathrm{dd}, J=7.8 \mathrm{~Hz}, 14.7 \mathrm{~Hz}, 1 \mathrm{H})$ \\
& & $2.76(\mathrm{dd}, J=3.6 \mathrm{~Hz}, 14.7 \mathrm{~Hz}, 1 \mathrm{H})$ \\
9 & 84.2 & $6.47-6.49(\mathrm{dxd}, J=3.9 \mathrm{~Hz}, 7.8 \mathrm{~Hz}, 1 \mathrm{H})$ \\
10 & 144.0 & $8.59(\mathrm{~s}, 1 \mathrm{H})$ \\
11 & 152.2 & $8.79(\mathrm{~s}, 1 \mathrm{H})$ \\
\hline
\end{tabular}

\subsection{Cyclobutanone 4}

This ketone was prepared by a two step sequence involving $\alpha$-bromination followed by $N$ alkylation with 6-chloropurine [23]. Regioisomers of the $N-7$ and $N-9$ (compound 9) alkylated 
products were formed and their structures determined by X-ray single crystal diffraction [23]. m.p. 60-62 ${ }^{\circ} \mathrm{C}$; IR $\left(\mathrm{cm}^{-1}\right) 1799\left(\mathrm{C}=\mathrm{O}\right.$ of cyclobutanone); $1715(\mathrm{C}=\mathrm{O}$ of ester $) ;{ }^{1} \mathrm{H}-\mathrm{NMR}\left(\mathrm{CDCl}_{3}\right): \delta 8.65(\mathrm{~s}$, $1 \mathrm{H}), 8.17(\mathrm{~s}, 1 \mathrm{H}), 7.90-7.88(\mathrm{~d}, J=8.0 \mathrm{~Hz}, 2 \mathrm{H}), 7.58-7.55(\mathrm{t}, J=7.0 \mathrm{~Hz}, 1 \mathrm{H}), 7.42-7.38(\mathrm{t}$, $J=7.8 \mathrm{~Hz}, 2 \mathrm{H}), 5.78-5.76(\mathrm{~d}, J=7.6 \mathrm{~Hz}, 1 \mathrm{H}), 4.77-4.76(\mathrm{~d}, J=5.2 \mathrm{~Hz}, 2 \mathrm{H}), 3.60-3.54(\mathrm{~m}, 1 \mathrm{H})$, $3.47-3.40(\mathrm{~m}, 1 \mathrm{H}), 3.26-3.19(\mathrm{dd}, J=8.8 \mathrm{~Hz}, 17.6 \mathrm{~Hz}, 1 \mathrm{H}) ;{ }^{13} \mathrm{C}-\mathrm{NMR}\left(\mathrm{CDCl}_{3}\right): \delta 196.9,166.6,152.3$, $151.6,151.5,144.0,133.8,131.6,129.7,129.2,128.8,68.9,65.0,45.3,33.3$.

\subsection{Photolysis of Ketone 4 in Acetonitrile spiked with Water}

A solution of ketone $4(71 \mathrm{mg}, 0.2 \mathrm{mmol})$ in $45 \mathrm{~mL}$ of acetonitrile and $0.036 \mathrm{~mL}$ (2.0 mmol) of water was irradiated for $3 \mathrm{~h}$. The solvent was removed under vacuum and the residue purified by preparative TLC (60\% ethyl acetate-hexane) to give $15 \mathrm{mg}(20.2 \%)$ of diastereomeric mixture of hemiacetal 5, $7 \mathrm{mg}(11.1 \%)$ of trans-alkene 7 and $40 \mathrm{mg}(63.5 \%)$ of the cis-alkene 8.

Benzoic acid 2-(6-chloro-purin-9-yl)-5-hydroxy-tetrahydro-furan-3-ylmethyl ester (5). ${ }^{1} \mathrm{H}-\mathrm{NMR}$ $\left(\mathrm{CDCl}_{3}\right): \delta 8.76(\mathrm{~s}, 1 \mathrm{H}), 8.29(\mathrm{~s}, 1 \mathrm{H}), 8.13-8.11(\mathrm{~d}, J=8.0 \mathrm{~Hz}, 2 \mathrm{H}), 7.64-7.59(\mathrm{t}, J=6.4 \mathrm{~Hz}, 1 \mathrm{H})$, $7.48-7.44(\mathrm{t}, J=8.0 \mathrm{~Hz}, 3 \mathrm{H}), 6.56-6.55(\mathrm{~d}, J=4.0 \mathrm{~Hz}, 1 \mathrm{H}), 4.70-4.68(\mathrm{dd}, J=4.0 \mathrm{~Hz}, 12.0 \mathrm{~Hz}, 1 \mathrm{H})$, $4.55-4.50(\mathrm{dd}, J=6.4 \mathrm{~Hz}, 11.6 \mathrm{~Hz}, 1 \mathrm{H}), 3.80-3.78(\mathrm{~m}, 1 \mathrm{H}), 3.66-3.59$ (dd, $J=10.0 \mathrm{~Hz}, 18.0 \mathrm{~Hz}, 1 \mathrm{H})$, 2.80-2.74 (m, 1H); MS: $\mathrm{m} / \mathrm{z} 361\left(\mathrm{M}^{+}-\mathrm{OH},{ }^{37} \mathrm{Cl}\right), 386\left(\mathrm{M}^{+}-\mathrm{OH},{ }^{35} \mathrm{Cl}\right)$.

E-1'-(6-Chloropurin-9-yl)-2'-benzoyloxyethene (7). ${ }^{1} \mathrm{H}$ NMR $\left(\mathrm{CDCl}_{3}\right): \delta 8.82(\mathrm{~s}, 1 \mathrm{H}), 8.32(\mathrm{~s}, 1 \mathrm{H})$, 8.10-8.08 (d, $J=8.0 \mathrm{~Hz}, 2 \mathrm{H}), 7.61-7.58(\mathrm{t}, J=7.0 \mathrm{~Hz}, 1 \mathrm{H}), 7.49-7.45$ (t, $J=7.6 \mathrm{~Hz}, 2 \mathrm{H}), 7.41-7.38$ (d, $J=14.4 \mathrm{~Hz}, 1 \mathrm{H}), 6.94-6.88(\mathrm{ddd}, J=6.4,14.4,20.8 \mathrm{~Hz}, 1 \mathrm{H}), 5.08-5.07(\mathrm{~d}, J=6.0 \mathrm{~Hz}, 2 \mathrm{H}) ;{ }^{13} \mathrm{C} \mathrm{NMR}$ $\left(\mathrm{CDCl}_{3}\right): \delta 166.3,152.8,151.8,151.0,143.0,133.5,132.4,130.3,129.9,128.7,124.0,117.1,62.7$; MS: $m / z 316\left(\mathrm{M}^{+},{ }^{37} \mathrm{Cl}\right), 314\left(\mathrm{M}^{+},{ }^{35} \mathrm{Cl}\right)$.

Z-1'-(6-Chloropurin-9-yl)-2'-benzoyloxyethene (8). ${ }^{1} \mathrm{H}-\mathrm{NMR}\left(\mathrm{CDCl}_{3}\right): \delta 8.80(\mathrm{~s}, 1 \mathrm{H}), 8.41(\mathrm{~s}, 1 \mathrm{H})$, 7.97-7.96 (d, $J=7.8 \mathrm{~Hz}, 2 \mathrm{H}), 7.59-7.56(\mathrm{t}, J=7.5 \mathrm{~Hz}, 1 \mathrm{H}), 7.45-7.42$ (t, $J=7.8 \mathrm{~Hz}, 2 \mathrm{H}), 7.11-7.10$ (d, $J=9.0 \mathrm{~Hz}, 1 \mathrm{H}), 6.16-6.12(\mathrm{q}, J=7.6,15.6 \mathrm{~Hz}, 1 \mathrm{H}), 5.03-5.02(\mathrm{~d}, J=6.6 \mathrm{~Hz}, 2 \mathrm{H}) ;{ }^{13} \mathrm{C}-\mathrm{NMR}\left(\mathrm{CDCl}_{3}\right)$ : $\delta 166.2,152.9,151.9,151.8,144.4,133.7,131.4,129.8,129.4,128.7,123.0,122.1,59.8 ; \mathrm{MS}: \mathrm{m} / \mathrm{z} 316$ $\left(\mathrm{M}^{+},{ }^{37} \mathrm{Cl}\right), 314\left(\mathrm{M}^{+},{ }^{35} \mathrm{Cl}\right)$.

\subsection{Photolysis of Ketone $\mathbf{4}$ in Methanol}

A solution of ketone $4(60 \mathrm{mg}, 0.17 \mathrm{mmol})$ in methanol $(50 \mathrm{~mL})$ was irradiated for $8 \mathrm{~h}$. Evaporation of the solvent under vacuum followed by chromatographic purification (gradient solvent mixture from $40 \%$ ethyl acetate-hexane to $60 \%$ ethyl acetate-hexane) yielded $7 \mathrm{mg}(13.2 \%)$ of cis-alkene $8,14 \mathrm{mg}$ (21.2\%) of diester 10, and $26 \mathrm{mg}(39.3 \%)$ methoxyacetal 9 as a diastereomeric mixture which was further separated by preparative TLC (40\% ethyl acetate-hexane).

Benzoic acid 2-(6-chloro-purin-9-yl)-5-methoxy-tetrahydro-furan-3-ylmethyl ester (9) (less polar anomer). ${ }^{1} \mathrm{H}-\mathrm{NMR}\left(\mathrm{CDCl}_{3}\right): \delta 8.59(\mathrm{~s}, 1 \mathrm{H}), 8.47(\mathrm{~s}, 1 \mathrm{H}), 7.64-7.62(\mathrm{~d}, J=7.6 \mathrm{~Hz}, 2 \mathrm{H}), 7.53-7.49$ (t, $J=7.4 \mathrm{~Hz}, 1 \mathrm{H}), 7.31-7.27(\mathrm{t}, J=7.2 \mathrm{~Hz}, 2 \mathrm{H}), 6.57-6.55(\mathrm{~d}, J=5.6 \mathrm{~Hz}, 1 \mathrm{H}), 5.30-5.27(\mathrm{~m}, 1 \mathrm{H})$, 
4.67-4.57 (dd, $J=4.6,11.0 \mathrm{~Hz}, 1 \mathrm{H}), 4.47-4.42(\mathrm{~m}, 1 \mathrm{H}), 3.48-3.42$ (m with overlapping s, 4H), 2.47-2.44 (dd, $J=7.6,12.8 \mathrm{~Hz}, 1 \mathrm{H}), 2.20-2.13(\mathrm{~m}, 1 \mathrm{H})$; MS: $m / z 390\left(\mathrm{M}^{+},{ }^{37} \mathrm{Cl}\right), 388\left(\mathrm{M}^{+},{ }^{35} \mathrm{Cl}\right)$.

Benzoic acid 2-(6-chloro-purin-9-yl)-5-methoxy-tetrahydro-furan-3-ylmethyl ester (9) (more polar anomer). ${ }^{1} \mathrm{H}-\mathrm{NMR}\left(\mathrm{CDCl}_{3}\right): \delta 8.59(\mathrm{~s}, 1 \mathrm{H}), 8.26(\mathrm{~s}, 1 \mathrm{H}), 7.84-7.82(\mathrm{~d}, J=7.6 \mathrm{~Hz}, 2 \mathrm{H}), 7.50-7.45(\mathrm{t}$, $J=7.8 \mathrm{~Hz}, 1 \mathrm{H}), 7.40-7.35(\mathrm{t}, J=7.8 \mathrm{~Hz}, 2 \mathrm{H}), 6.40-6.39$ (d, $J=4.0 \mathrm{~Hz}, 1 \mathrm{H}), 5.44-5.43(\mathrm{~d}, J=4.8 \mathrm{~Hz}$, $1 \mathrm{H}), 4.59-4.57(\mathrm{~d}, J=7.6 \mathrm{~Hz}, 2 \mathrm{H}), 3.48-3.42$ (m with overlapping s, 4H), 2.80-2.73 (m, 1H), 2.03-1.99 (dd, $J=3.6,14.0 \mathrm{~Hz}, 1 \mathrm{H})$; MS: $\mathrm{m} / \mathrm{z} 390\left(\mathrm{M}^{+},{ }^{37} \mathrm{Cl}\right), 388\left(\mathrm{M}^{+},{ }^{35} \mathrm{Cl}\right)$.

Benzoic acid 2-(6-chloro-purin-9-ylmethyl)-3-methoxycarbonyl-propyl ester (10). ${ }^{1} \mathrm{H}-\mathrm{NMR}\left(\mathrm{CDCl}_{3}\right)$ : $\delta$ $8.70(\mathrm{~s}, 1 \mathrm{H}), 8.23(\mathrm{~s}, 1 \mathrm{H}), 7.91-7.90(\mathrm{~d}, J=7.6 \mathrm{~Hz}, 2 \mathrm{H}), 7.60-7.57(\mathrm{t}, J=7.0 \mathrm{~Hz}, 1 \mathrm{H}), 7.46-7.43$ (t, $J=7.8 \mathrm{~Hz}, 2 \mathrm{H}), 4.58-4.47(\mathrm{~m}, 2 \mathrm{H}), 4.41-4.31(\mathrm{~m}, 2 \mathrm{H}), 3.12-3.03(\mathrm{~m}, 1 \mathrm{H}), 2.59-2.47(\mathrm{~m}, 2 \mathrm{H}) ;{ }^{13} \mathrm{C}-$ NMR $\left(\mathrm{CDCl}_{3}\right): \delta 171.7,166.2,152.3,151.4,145.7,133.7,131.6,130.2,129.6,129.4,128.7,64.7$, 52.3, 45.4, 35.9, 33.7; MS: $m / z 390\left(\mathrm{M}^{+},{ }^{37} \mathrm{Cl}\right), 388\left(\mathrm{M}^{+},{ }^{35} \mathrm{Cl}\right)$.

\subsection{Photolysis of Ketone $\mathbf{4}$ in Acetone}

A solution containing $100 \mathrm{mg}(0.28 \mathrm{mmol})$ of ketone 4 in $90 \mathrm{~mL}$ of acetone was irradiated for $6 \mathrm{~h}$. The solvent was removed and the residue purified by preparative TLC (30\% ethyl acetate-hexane) to give $18 \mathrm{mg}$ (20.4\%) of trans-alkene 7 , and $21 \mathrm{mg}$ (23.9\%) of cis-alkene 8 . The spectral properties for each of these fractions were identical for the corresponding derivatives reported above.

\subsection{Photolysis of Ketone 4 in Benzene}

A solution of ketone 4 (120 mg, $0.34 \mathrm{mmol})$ in $80 \mathrm{~mL}$ of benzene was irradiated for $3 \mathrm{~h}$. Removing of the solvent under vacuum followed by chromatographic purification (30\% ethyl acetate-hexane) yielded $20 \mathrm{mg}$ (18.7\%) of cis-alkene 8 and $35 \mathrm{mg}$ (32.7\%) of trans-alkene 7 with identical spectral properties as reported above.

\section{Conclusions}

The direct irradiation of the bicyclic cyclobutanone $\mathbf{3}$ proceeds by isomerisation to a transient oxacarbene which can insert into the $\mathrm{N}-9 \mathrm{~N}-\mathrm{H}$ bond of 6-chloropurine to give the corresponding bicyclic nucleoside analogues. The choice of 6-chloropurine was based on its solubility in common organic solvents such as acetonitrile or THF, ensuring homogeneity in order to maximize photochemical efficiency. Furthermore, nucleophilic aryl substitution of the $\mathrm{C}(6)-\mathrm{Cl}$ function by $\mathrm{NH}_{2}$ has been shown to occur under mild conditions in order to access the adenine derivatives [6]. While yields are quite modest, this approach represents one of the most simple routes to these derivatives. Another cyclobutanone 4 in which the purine nucleobase is attached undergoes photochemical ringexpansion with water or methanol to give photoadducts which represent the isonucleoside class of derivatives. A competing side reaction involving cycloelimination yields purinyl base substituted alkenes, the distribution of which is solvent dependent. These compounds are of interest as intermediates in the synthesis of cyclopropane carbocyclic nucleosides. The photolysis of $\mathbf{4}$ in methanol produced an unexpected Norrish I photoadduct $\mathbf{1 0}$ which on hydride reduction would 
generate the corresponding diol representing an acyclic nucleoside analogue. These latter studies are currently being extended to include pyrimidine nucleobases as part of a general program for the preparation of cyclobutane based nucleoside analogues.

\section{Acknowledgements}

We would like to thank NSERC for funding this project. AE would like to acknowledge the support in the form of a graduate scholarship from the Government of Egypt.

\section{References and Notes}

1. Ewald, B.; Sampath, D.; Plunkett, W. Nucleoside analogs: molecular mechanisms signaling cell death. Oncogene 2008, 27, 6522-6537.

2. Bellezza, I.; Tucci, A.; Minelli, W. 2-Chloroadenosine and human prostate cancer cells. Anticancer Agents Med. Chem. 2008, 8, 783-789.

3. De Clerq, E.; Neyts, J. DNA RNA Chain Terminators. In Handbook of Experimental Pharmacology; Springer-Verlag: Heidelberg, Germany, 2009; Volume 189, 53-84.

4. Ohno, H.; Terui, T.; Kitawaki, T.; Chida, N. Total synthesis of dapiramicin B. Tetrahedron Lett. 2006, 47, 5747-5750.

5. Angelini, M.P.; Lee-Ruff, E. A novel photochemical synthesis of dideoxyfuranosyl disaccharides. Tetrahedron Lett. 1998, 39, 8783-8786.

6. Lee-Ruff, E.; Wan, W-Q.; Jiang, J.-L. A Novel Approach toward the Synthesis of Chiral 2,3Dideoxy Nucleosides and Their Carbocyclic Analogs. J. Org. Chem. 1994, 59, 2114-2118.

7. Lee-Ruff, E.; Xi, F.; Qie, J.H. Enantioselective Preparation of 2',3'-Dideoxynucleosides and Their Analogs from Ring-Expansion of Cyclobutanones. 2. Synthesis of 2',3'-Dideoxyribosides and (1S,3R)-1-Amino-3-(hydroxymethyl)cyclopentane. J. Org. Chem. 1996, 61, 1547-1550.

8. Lee-Ruff, E.; Ostrowski, M.; Ladha, A.; Stynes, D. V.; Vernik, I.; Jiang, J.-L.; Wan, W.-Q.; Ding, S.-F.; Joshi, S. Synthesis and HIV Inhibition Activity of 2',3'-Dideoxy-3'-C-hydroxymethyl Nucleosides. J. Med. Chem. 1996, 39, 5276-5280.

9. Lee-Ruff, E.; Margau, R. Photochemical synthesis of novel dideoxynucleosides. Nucleosides, Nucleotides Nucleic Acids 2001, 20, 185-196.

10. Zhong, J.-H.; Fishman, A.; Lee-Ruff, E. Photochemistry on Soluble Polymer Supports: Synthesis of Nucleosides. Org. Lett. 2002, 4, 4415-4417.

11. Ghazi, H.; Lee-Ruff, E. Synthesis of fluorocyclobutanones and their use in the synthesis of fluoronucleosides. J. Fl. Chem. 2005, 126, 1565-1569.

12. Mladenova, G.; Lee-Ruff, E. Cyclobutanone photoadducts of HCN and malononitrile: useful intermediates for the synthesis of C-nucleosides. Tetrahedron Lett. 2007, 48, 2787-2789.

13. Lee-Ruff, E.; Wells, D. Bicyclic Nucleoside Synthesis-A Photochemical Approach. Nucleosides, Nucleotides Nucleic Acids 2008, 27, 484-494.

14. Lee-Ruff, E.; Mladenova, G. Enantiomerically Pure Cyclobutane Derivatives and Their Use in Organic Synthesis. Chem. Rev. 2003, 103, 1449-1483.

15. Lee-Ruff, E. Synthesis of cyclobutanes. Chem. Cyclobutanes 2005, 1, 281-355. 
16. Lee-Ruff, E.; Hayes, I.E.E.; Kazarians-Moghaddam, H. Photocycloeliminations of bicyclic cyclobutanones. I. Solvent effects on distribution of products. Struct. Chem. 1991, 2, 175-83.

17. Mathe, C.; Perigaud, C. Recent approaches in the synthesis of conformationally restricted nucleoside analogues. Eur. J. Org. Chem. 2008, 1489-1505.

18. Dyguda, E.; Szefczyk, B.; Sokalski, W.J. The Mechanism of Phosphoryl Transfer Reaction and the Role of Active Site Residues on the Basis of Ribokinase-like Kinases. Int. J. Mol. Sci. 2004, 5, 141-153.

19. Miyazaki, H.; Ohkawa, N.; Nakamura, N.; Ito, T.; Sada, T.; Oshima, T.; Koike, H. Lactone and cyclic ether analogs of platelet-activating factor. Synthesis and biological activities. Chem. Pharm. Bull. 1989, 37, 2379-2390

20. Machiguchi, T.; Okamoto, J.; Takachi, J.; Hasegawa, T.; Yamabe, S.; Minato, T. Exclusive Formation of $\alpha$-Methyleneoxetanes in Ketene-Alkene Cycloadditions. Evidence for Intervention of Both an $\alpha$-Methyleneoxetane and the Subsequent 1,4-Zwitterion. J. Am. Chem. Soc. 2003, 125, 14446-14448.

21. Nair, V. Antiviral isonucleosides: discovery, chemistry and chemical biology. Recent Adv. Nucleoside: Chem. Chemther. 2002, 149-166.

22. Zhang, S.; Switzer, C.; Chaput, J.C. The Resurgence of Acyclic Nucleic Acids. Chem. Biodivers. 2010, 7, 245-258.

23. Ebead, A.; Lee-Ruff, E. York University, Toronto, Canada. Unpublished work.

24. Haas, Y. Photochemical $\alpha$-cleavage of ketones: revisiting acetone. Photochem. Photobiol. Sci. 2004, 3, 6-16.

25. Smith, R.D.; Simmons, H.E. Norcarane. Org. Synth. 1973, Coll. Vol. 5, 855; 1961, 41, 72.

Sample Availability: Samples of the compounds are available from the authors.

(C) 2010 by the authors; licensee MDPI, Basel, Switzerland. This article is an Open Access article distributed under the terms and conditions of the Creative Commons Attribution license (http://creativecommons.org/licenses/by/3.0/). 